\title{
Is new always better than old? On the treatment of fiscal policy in Keynesian models
}

\author{
Sebastian Dullien \\ Professor of International Economics, HTW Berlin - University of Applied Sciences, Germany
}

\begin{abstract}
The paper traces the treatment of fiscal policy in mainstream Keynesian models, from IS-LM over simple dynamic New Keynesian models to the most sophisticated New Keynesian dynamic stochastic general equilibrium (DSGE) models and compares it with stylized empirical facts on the impact of fiscal policy. It is found that the traditional simple Keynesian models such as IS-LM and Mundell-Fleming actually come to very similar conclusions on the effectiveness of fiscal policy as the most complex DSGE models, and are very much in line with stylized empirical facts found in most recent studies. In contrast, the dynamic models used during most of the 1990s and 2000s perform very poorly. It is hence questioned whether the change in modeling approaches over the past 60 years really constitutes progress in economic insight given the growing complexity of modern models.
\end{abstract}

Keywords: fiscal policy, austerity, IS-LM, DSGE, new Keynesian models

JEL codes: E12, E27, E62

\section{INTRODUCTION}

Over the past 60 years, the view on fiscal policy as a macroeconomic stabilization tool among both practitioners as well as academic economists has experienced wide swings. While in the 1950s and 1960s, and up into the 1970s, there was a strong belief in the effectiveness of stabilization policies using public expenditure and tax rates, fiscal policy had fallen completely into disregard in the 1980s and 1990s. During this time, economists not only claimed the inefficiency of fiscal policy, but sometimes even claimed that cutting back deficits decisively would lead to an expansion of output.

Fiscal policy as a stabilization device with expected traditional Keynesian effects began to reemerge both in the political and the academic arena after the recession of 2001 and made its full comeback during the global financial and economic crisis following the meltdown of the US subprime market in 2008. In a similar direction, the experience of austerity measures after the onset of the European debt crisis in 2010 brought back doubts on the sustainability of fiscal stimulus, but the experienced drastic contraction of output led to an increasing skepticism against ideas of an expansionary fiscal tightening.

Against the background of this development, this paper will trace the treatment of fiscal policy in the most widely used Keynesian models over time. It will first give a short history on the predominant view among policymakers and academics on fiscal policy since the publication of Keynes's General Theory. It will then outline what 
the latest empirical research is saying on the effectiveness of fiscal policies. Finally, it will check how far the stylized facts found in empirical data are mimicked by different mainstream Keynesian models. This exercise will start with the old Keynesian models still ubiquitous in textbooks such as IS-LM and the Mundell-Fleming model, move on to the standard dynamic stochastic general equilibrium (DSGE) models used in the early 2000s and culminate in the post-crisis versions of the large-scale DSGE models currently used by the IMF and the central banks. ${ }^{1}$ A final section will present some thoughts on the progress made in modeling fiscal policy in the decades since the first publication of the IS-LM model.

\section{SHIFTING VIEWS ON FISCAL POLICY}

Immediately after World War II, there was a clear consensus among policymakers and academics on the standard Keynesian argument as presented in the General Theory. According to Keynes (1936), fiscal policy could be used to prevent aggregate demand falling short of aggregate supply. Moreover, with the exchange rates of the major currencies fixed under the Bretton Woods regime, monetary policy was less flexible and therefore fiscal policy was seen as a tool of choice for macroeconomic management.

This view started to shift with the picking-up of inflation after the Vietnam War and after the first oil price shock in 1973. As the toxic macroeconomic environment only produced increasing inflation without steady growth even as industrialized countries were running significant budget deficits, policymakers began to doubt the suitability of fiscal policy for stabilization purposes. These growing doubts were further fuelled by academic models brought forward in the Rational Expectations Revolution triggered by Lucas (1972). In these 'New Classical' models, macroeconomic policies were depicted as being without lasting influence on the real economy. According to this strand of literature, macroeconomic fluctuations were seen as a result of individuals' optimal reactions to shocks to technology or taste. As economic agents were rational, they could anticipate any attempt by policymakers to increase output or employment and adjust their actions accordingly. In the end, expansionary monetary or fiscal policy would only be able to influence inflation, but not real output or employment.

Monetary policy regained quickly its standing as a policy tool, especially after the Volcker shock in the US in the early 1980s. Disinflation experiences in Europe demonstrated that central banks' actions had the effect predicted by standard Keynesian models, with tight monetary policy leading to falling GDP growth. Academic models under the label of 'New Keynesian Economics' mirrored this experience by introducing price and wage stickiness into models with rational expectations. As the private sector in these models was not able to adjust prices and wages instantaneously to external shocks, monetary policy could help keep the economy at full employment by adjusting the interest rate.

Fiscal policy, by contrast, continued to be treated with disdain. As decision and implementation lags in fiscal policymaking were seen to be much longer than for monetary policymaking, fiscal tools were not considered appropriate stabilization instruments. In fact, the academic profession over years did not concern itself much with fiscal policy. In the 1996 first edition of David Romer's widely used graduate

1. Of course, there have been many more models of Keynesian provenance, including a wide range of Post-Keynesian model. However, for space constraints, this paper is limited to models which have made a significant impact either on economic textbooks or on policymakers. 
textbook Advanced Macroeconomics, the term 'fiscal policy' is not even found once in the index while the term 'monetary policy' is mentioned 36 times.

The comeback of fiscal policy began in the early 2000s, after the bursting of the dot-com bubble. US President George W. Bush's tax cuts were supported even by conservative economists not only as a way to improve long-term incentives, but also to give the economy a short-term stimulus (Feldstein 2002). Also in academic publications, a gradual shift could be detected at least in the US (see Blinder 2006). However, in Europe, the whole argument of fiscal policy being able to influence the business cycle was still being snubbed through most of the 2000s.

The small trickle in changing attitudes on fiscal policy turned into a sea-change after the meltdown of the US sub-prime market and the default of the investment bank Lehman Brothers in 2008. With the world economy standing at the brink of an abyss, all major OECD countries as well as the most important emerging markets engaged in expansionary stimulus measures, supported not only by institutions such as the IMF and the OECD, but also by most academic economists.

Parallel to this, in academia, a new class of dynamic New Keynesian models has emerged which can sensibly be used to simulate the impact of fiscal policy measures. International organizations especially (such as the IMF or the European Central Bank) now use complex models which combine rational expectations and a micro-foundation with sticky prices and monopoly power in goods and labor markets as well as consumers who are taken to behave according to rules-of-thumb instead of a perfect optimization of their utility function. Results obtained confirm fiscal policy as effective in stabilizing aggregate demand; more so in times of extraordinary economic weakness.

However, the new ascent of fiscal policy has not remained undisputed. First, with the onset of the euro crisis, the focus has shifted towards potential negative sideeffects. Both policymakers and academic economists warn about detrimental longterm effects of government debt. One important study - Reinhart and Rogoff's (2009) - claims that economic growth slows down once a certain threshold of public debt is reached. In addition, the recent experience of markets turning against European governments and pushing up long-term interest rates to a point where there might be a self-fulfilling solvency crisis has left a lasting apprehension among many policymakers. In some parts of the economics profession, the work of Alberto Alesina has again gained followers, claiming that harsh austerity actually can produce pro-growth effects if it is managed to turn expectations about future output around.

Ironically, however, the euro crisis itself has at the same time provided more evidence of the (traditional Keynesian) effectiveness of fiscal policy. With harsh austerity packages being passed, the economic outlook of the crisis countries has generally deteriorated strongly. There is now an emerging debate whether the current (European) approach to budget consolidation through strict austerity-only policies might have been misguided (DeLong 2012; Gros 2011).

\section{THE EMPIRICS OF FISCAL POLICY: WHAT DO WE KNOW?}

So, what do we really know about the empirics of the impact of fiscal policy, especially of stimulus packages in economic crisis and austerity measures to reduce government deficits and public debt? If we just looked at the literature in an unstructured and uncritical way, the answer would be: Very little. There are prominent economists claiming that debt-financed changes in government spending have multipliers close to 0 (Barro 2009) and there are studies claiming that these multipliers might go up as far 
as 3.5 in recessions (Auerbach and Gorodnichenko 2011). There is literature claiming that there are non-Keynesian effects of strong fiscal tightening which actually lead to an acceleration of economic growth (Giavazzi and Pagano 1990; Alesina and Ardagna 1998) and literature clearly showing the negative effect on output of all fiscal tightening measures (IMF 2010a).

This section therefore will first look at the empirical evidence in the form of case studies on fiscal policy reaction in the Global Financial and Economic Crisis or Great Recession of 2008-2009 for the two G7 countries with the largest stimulus measures, the US and Germany. Next we will track the impact of the austerity imposed after the onset of the euro crisis in 2010. This experience will be contrasted with the most important pieces from empirical literature both in favor of and in opposition to nonKeynesian effects. Finally, a list of stylized facts of the empirical impact of fiscal policies will be drawn up.

\subsection{Anecdotal experiences from the Great Recession and the euro crisis}

The Great Recession can be seen as one natural experiment on the impact of fiscal policies. Already in 2008, countries particularly hard hit by the end of the real estate boom of the 2000s, such as the US, the UK and Spain, had introduced significant stimulus packages. As the US sub-prime crisis spread to the rest of the industrialized world after the default of the investment bank Lehman Brothers in September, most of the other G20 countries also hurriedly passed huge fiscal stimulus packages. For the OECD as a whole, the size of these stimulus packages was estimated to be an equivalent of 3.4 percent of GDP, with most of it coming into effect during the course of 2009 and 2010 (OECD 2009).

Two benchmarks are important to judge the effectiveness of fiscal policy here. First, has economic recovery actually been quicker with fiscal stimulus? This can be discovered by checking how far economic outcomes actually deviated from economic projections prior to the implementation of the stimulus. Second, do the turning points in GDP coincide with the passage of fiscal stimulus measures?

Most major stimulus packages as a reaction to the Great Recession were passed in early 2009. In the United States of America, the 'American Recovery and Reinvestment Act of 2009,' with a headline figure of almost US $\$ 800$ billion, was signed into law on February 17, 2009. The German stimulus package 'Konjunkturpaket II' was decided by the government in January 2009 and came into effect after votes of both chambers of parliament in early March 2009. In both cases, first parts of the funds were disbursed quickly afterwards, contradicting the general view of long implementation lags of fiscal policy. In Germany, the 'Abwrackprämie' (a bonus of $€ 2500$ for everyone exchanging a car more than 9 years old against a new one) could be drawn upon immediately. Already in March 2009, car manufacturers were reporting record domestic sales. In the US, disbursement of money was slightly slower, with changes in the payroll tax coming into effect only in June.

In fact, many countries' economies started to recover quickly after the enactment of stimulus packages, with a turn in business expectations playing a central role. For space reasons and the sake of detailed analysis, we concentrate on the US and Germany. In the US, the Institute for Supply Management's Purchasing Manager Index started to increase in March 2009, just after the stimulus package was signed into law. Similarly, a turning point of the German Ifo index for the business climate can be seen after the passage of the German stimulus package (Figures 1 and 2). 


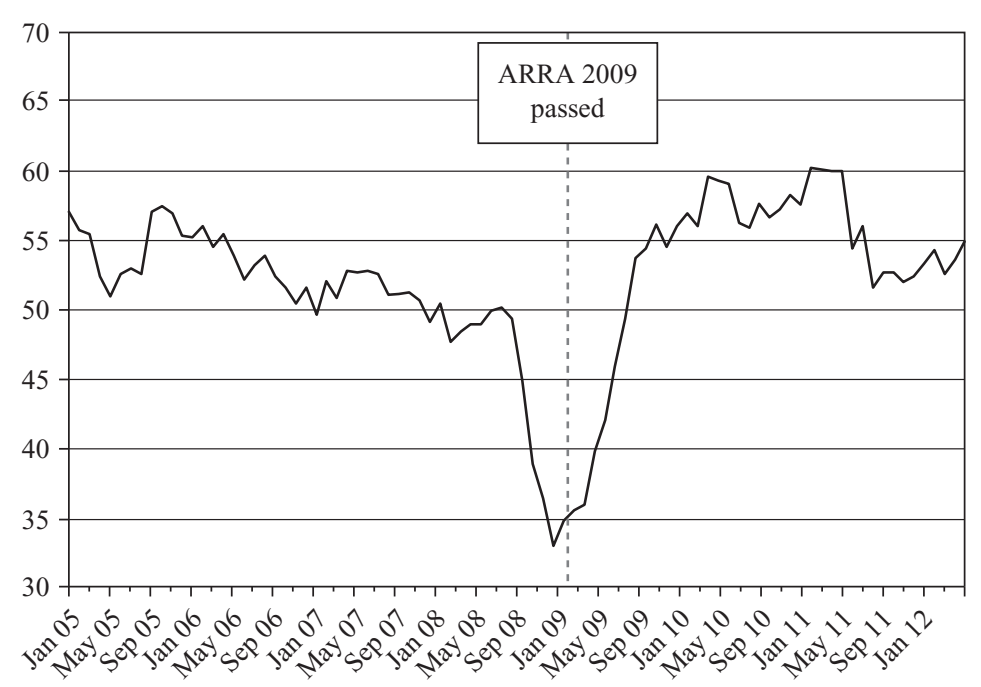

Source: Federal Reserve.

Figure 1 US business confidence and fiscal stimulus during the Great Recession

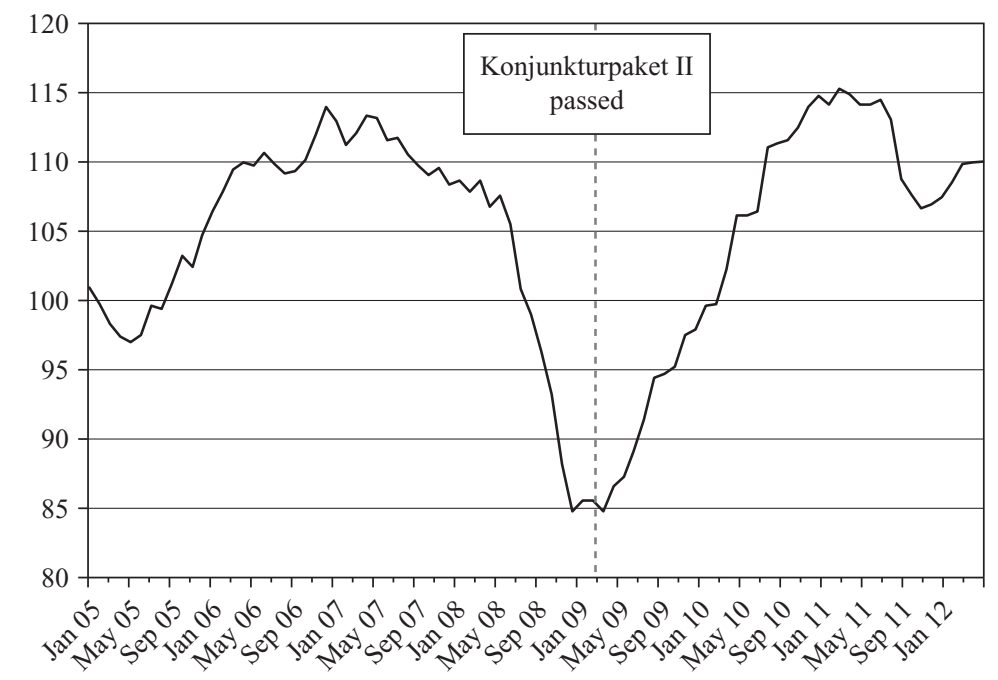

Source: Ifo Institute.

Figure 2 German business confidence and fiscal stimulus during the Great Recession

However, the stimulus packages did not only have an impact on the mood of the corporate sector, but also on output and investment. Both in the US and in Germany, GDP started to recover quickly after the enactment of the stimulus packages (Figure 3). In the US, output started to increase in the third quarter, as citizens at large started to sense an increase in disposable income induced by the cut in payroll taxes. 


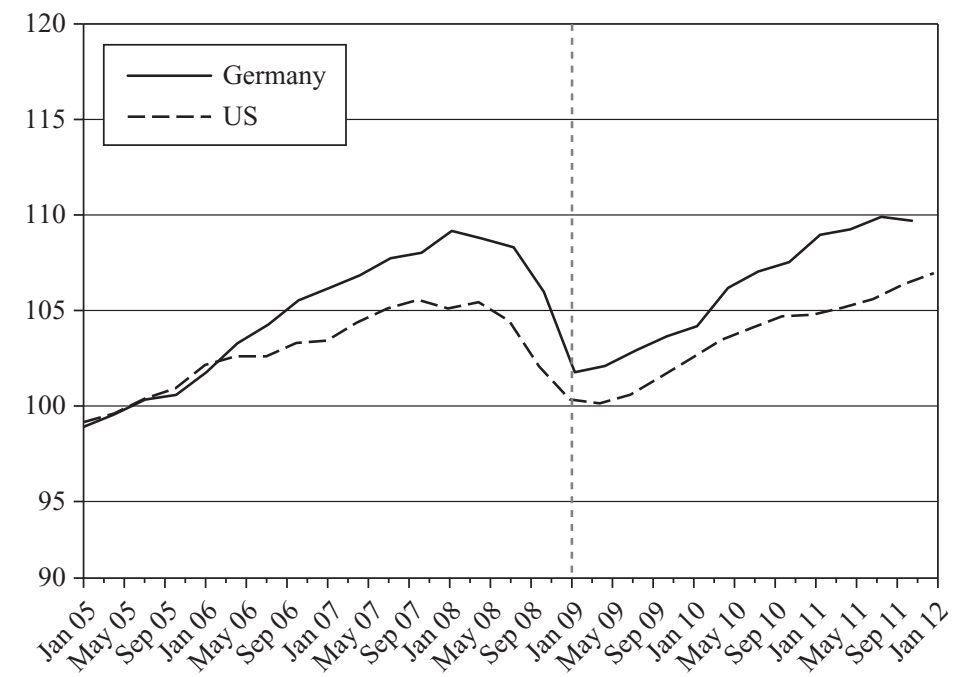

Note: $2005=100$.

Source: Federal Reserve, Bundesbank.

Figure 3 Fiscal stimulus and GDP trajectory in the US and Germany during the Great Recession

In Germany, output had already increased in the second quarter when the car industry ramped up production thanks to subsidized domestic demand. In both cases, private fixed capital formation started to recover quickly as well.

The impact of the stimulus package also surprised professional economists. Recovery turned out to be more brisk than had been predicted by most forecasters. From the early summer of 2009 onwards, the IMF saw itself forced to revise its forecast upward repeatedly (see Figures 4 and 5). ${ }^{2}$ While the size and composition of the stimulus packages had largely been known in the summer of 2009, this can be seen as an indicator that the IMF's economists were surprised how strongly the stimulus affected the real economy.

While the Great Recession provides a useful case study to establish the effectiveness of fiscal stimulus, the euro crisis since 2010 presents an interesting case for looking at the impact of strong fiscal tightening. After Greece started to have problems financing its huge budget deficit of more than 10 percent of GDP in financial markets, strict austerity had to be imposed as per EU and IMF rescue packages. Similar policies were enacted in other crisis countries such as Ireland, Portugal and Spain with the aim of bringing the budget deficit below the EU's 3 percent threshold in a short period of time. However, growth-enhancing confidence effects could not be spotted.

After the stability programs were passed, both the EU and the IMF saw themselves forced to repeatedly revise their growth forecasts downwards. The IMF's forecast

2. Due to the statistical overhang, the overall output outlook for 2009 did not change much since, mathematically, the last quarters of a year have only a marginal impact on the overall annual growth rate of GDP. The change in the outlook is therefore mostly reflected in the forecasts for 2010 . 


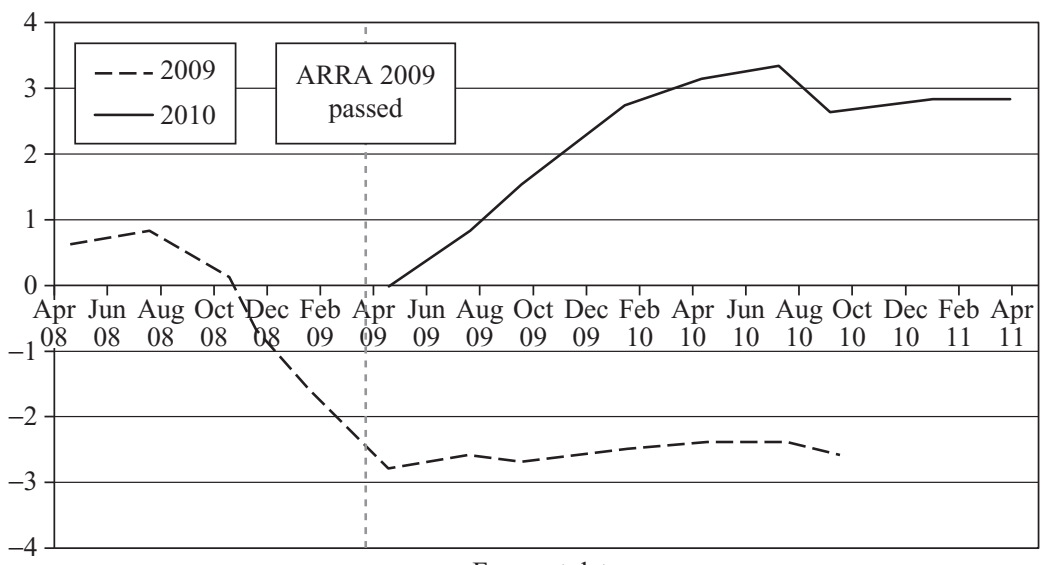

Forecast date

Figure 4 Forecast revisions by the IMF, US GDP 2009/2010

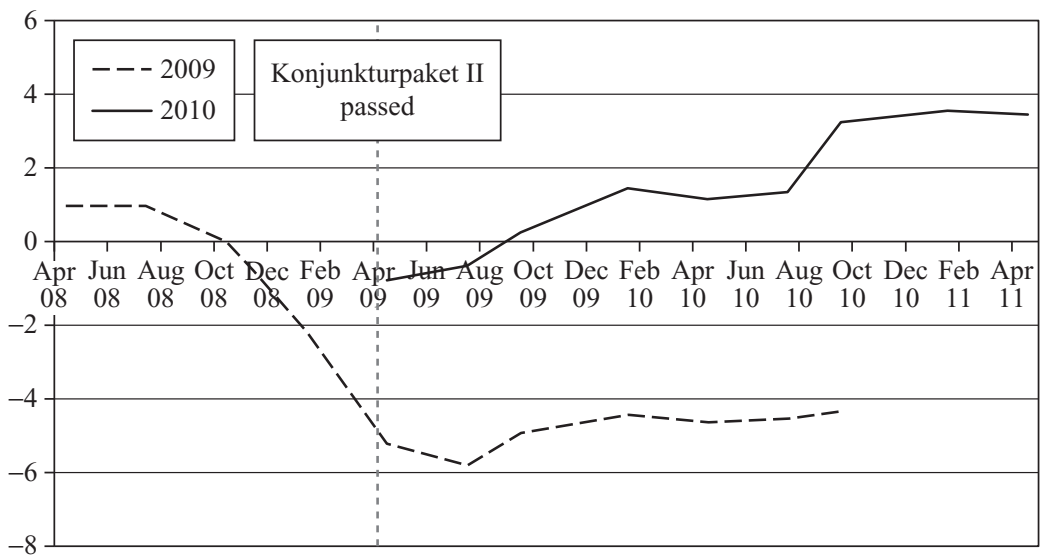

Forecast date

Figure 5 Forecast revisions by the IMF, German GDP 2009/2010

revisions for Greece are shown in Figure 6. In the first review of the impact of the stability programs from September 2010, the Greek economy was seen to return to decent economic growth in 2012 and overall contraction of GDP was projected to amount to about 8 percent (IMF 2010b). In the fifth review from December 2011, the recession was projected to continue until 2013 and the overall contraction of GDP was estimated at about 16 percent (IMF 2011). At the time of writing, in May 2012, deep recessions as a result of austerity could be anticipated for Spain and Italy and were reflected in the most recent forecasts of the EU Commission (EU Commission 2012). Only half a year earlier, the forecasts had indicated an ongoing recovery for these countries (EU Commission 2011) even though austerity measures had already been decided. Thus, the experience in the euro crisis underlines the stylized facts discussed above that fiscal policy is very effective, especially when interest rates are already close to the zero bound, and that it works in the direction predicted by traditional Keynesian arguments. 
12 Review of Keynesian Economics, Inaugural Issue

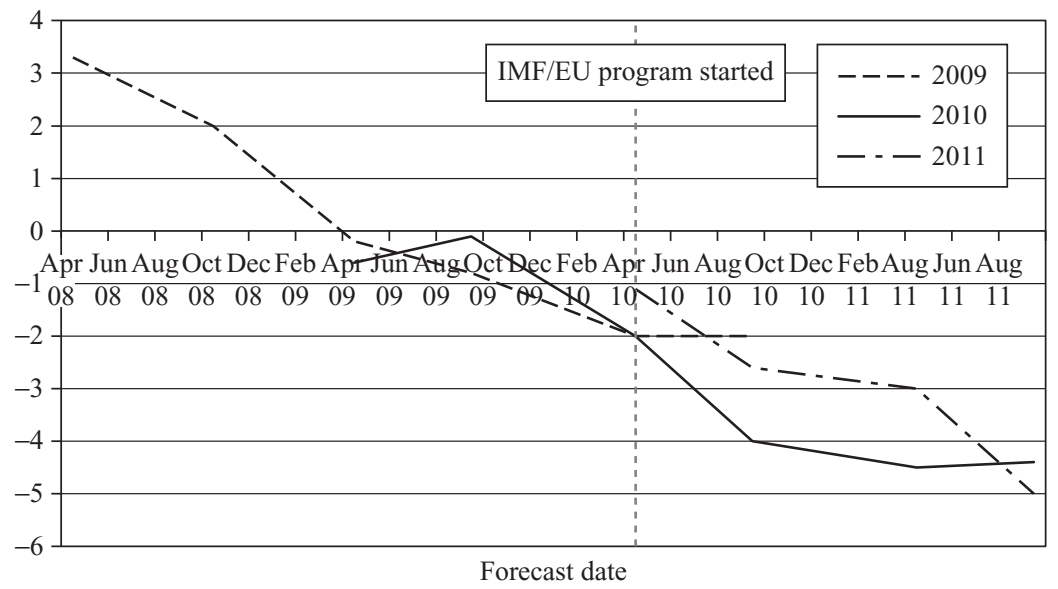

Figure 6 Forecast revisions by the IMF, Greek GDP 2009-2011

While these experiences certainly do not give a quantitative assessment of the size of the fiscal multipliers, one can infer from them that (a) the multiplier is clearly positive and (b) that it is bigger than international organizations such as the EU commission and the IMF had perceived. As the IMF itself has stated that one should work with multipliers between 0.3 and 1 for small and medium-sized economies (Spilimbergo et al. 2009), the forecast revisions might be a hint that empirical multipliers both in the Great Recession and in the euro crisis have been significantly above this value. $^{3}$

\subsection{Quantitative studies and non-Keynesian effects}

In addition to case studies, empirical studies in the form of panel analysis have for a long time shaped the thinking of the profession on fiscal policy. Especially the contributions by Alberto Alesina and his various co-authors had a lasting impact. In their seminal contributions Alesina and Ardagna $(1998 ; 2009)$ had claimed that large fiscal adjustments could even be expansionary if they are based on spending cuts rather than tax increases and if the cuts are enacted boldly. Moreover, they claimed that large increases in public spending did not have the expansionary effect usually assumed by traditional Keynesian models. According to reports in popular news media, Alesina's work has strongly influenced the design of the austerity packages in Europe (Coy 2010).

Alesina and Ardagna had identified from OECD data a number of episodes in which fiscal policy has changed substantially (as measured in changes of the cyclically-adjusted primary balance). They had then looked into spending and revenue data to see which side of the budget had led to the changes; and, in a third step,

3. Of course, this conclusion has to be treated carefully since, logically, there is also the possibility that forecast revisions (upward in the case of fiscal expansion in the Great Recession and downward in the case of austerity in the euro crisis) were caused by additional, exogenous factors not foreseen by the forecasters. 
had analysed the changes in macroeconomic variables around the time of changes in the fiscal stance. The work by Alesina and Ardagna was very attractive to some economists as it seemed to underline the idea of non-Keynesian effects of fiscal policy described formerly for single cases (see Giavazzi and Pagano 1990), this time with a large international data set.

However, lately, the work by Alesina has been questioned, as have other empirical papers on alleged non-Keynesian effects of fiscal policy. For example, the IMF (2010a) claims that the selection approach used by Alesina and Ardagna 'biases the analysis toward downplaying contractionary effects and overstating expansionary ones' (p. 94). The IMF economists criticize that, first, the standard cyclical adjustment methodology is not able to remove swings in government revenue stemming from boom-and-bust cycles in asset prices. Second, as it has only looked at the ex post change in budget balance, episodes in which a country with a large planned fiscal tightening experienced a sharp recession which made it reverse its course were excluded from the sample!

Moreover, many data points in the Alesina and Ardagna paper seem to be falsely selected. The IMF examines five of the largest consolidation episodes in the Alesina and Ardagna data set and comes to the conclusion that these can be explained mostly by one-off factors such as one-time capital transfers between the general government and other public entities, privatization revenues, or special factors such as increased tax revenue caused by asset price booms.

In fact, the problems seem to be even more serious than the IMF describes. If one takes the case of Germany, all four data points included in the Alesina and Ardagna data set turn out to be baseless. Using OECD data, the two authors have identified two years of strong spending cuts, 1996 and 2000, and two years of strong increases in government spending, 1995 and 2001. The swings indeed look impressive: the reported expenditure-to-GDP ratio jumps from 48 percent of GDP in 1994 to 53.8 percent in 1995, and drops to 49 percent in 1996, with similar changes in the structural budget deficit (reported with a peak of more than 9 percent of GDP in 1995). A similarly impressive swing is recorded around 2000: the expenditure-to-GDP ratio drops from 48.3 percent of GDP in 1999 to 45.1 percent in 2000, and jumps again to 47.5 percent in 2001 . The problem is that these swings do not show any underlying change in the fiscal stance, but are statistical artifacts. In 1995, there was a largescale debt transfer of Treuhand (the East German trust agency) and East German housing debt onto the government's books, amounting to 6.8 percent of GDP (IMF 2010a, p. 118). As this was booked as a one-time government spending, the expenditure ratio rose in 1995 only to fall back in 1996. We observe a similar situation that explains the movements around 2000. In that year, the German government auctioned off mobile phone licenses for $€ 50$ billion, more than 2 percent of GDP. As this auction is seen as a sale of non-tangible assets, it is booked as negative capital expenditure and hence lowers the reported expenditure-to-GDP ratio significantly which leads to the reported strongly restrictive fiscal policy in 2000 and a very expansionary fiscal policy in the following year. ${ }^{4}$

4. A similar point can be made for a number of European countries and their 'fiscal consolidation' introduced around the year 2000. Mobile phone license fees have by convention been booked as 'negative capital expenditure' and hence lowered reported government spending in the relevant year. For a number of countries, these proceeds have been significant enough to lead Alesina and Ardagna to include these years as years of extraordinary fiscal restraint. 
While one would have to re-run the regressions with a corrected data set to see whether the Alesina and Ardagna results might hold with corrected data, the more fundamental problems raised by the IMF cannot be corrected that easily.

The IMF has thus chosen a different approach. The staff have gone back through budget documents, central bank reports and country reports to the IMF for 17 OECD countries over the years 1978 to 2009 and have assembled a new data set based on policy decision episodes in which severe fiscal tightening measures were enacted (Devries et al. 2011). This new data set has been used to empirically identify the impact of fiscal tightening on output and domestic demand (IMF 2010a). While this approach is still open to methodological problems, it seems to gain increasing acceptance that it provides an improvement over using aggregate figures devoid of adequate institutional specifics (Perotti 2011).

The IMF's stylized facts seem therefore to be the best in terms of what we have to understand the impact of fiscal tightening (and hence fiscal policy more generally):

- Fiscal tightening has the impact expected by traditional Keynesian models: ceteris paribus, it depresses output and private domestic demand;

- The impact of fiscal tightening is larger if interest rates are close to zero and hence monetary policy ceases to be effective;

- The impact of fiscal policy is larger for countries with a fixed exchange rate;

- The impact of fiscal policy is smaller for open economies;

- The impact is smaller if the government has a difficult solvency situation;

- Tax-based consolidation programs have a smaller impact than spending-based consolidation programs; yet the difference is mainly due to the fact that monetary policy reacts more strongly in the face of spending cuts and hence counteracts much of the negative impact. ${ }^{5}$

Of course, even this simple list is still open to debate, and some of the stylized facts might be due to specific institutional factors in some countries (since the number of countries in the sample is still relatively small), as the exposition in UNCTAD (2011, chapter 3 ) shows. The interaction with other policy areas, especially, remains very much disputed. For example, the conclusion that fiscal tightening has a larger impact when interest rates are already close to zero depends crucially on the assumption that monetary policy reacts to the output gap and inflation with a reaction similar to the Taylor rule. If monetary policy does not follow the Taylor rule (that is, because authorities are not certain about the output gap), this conclusion might fall apart. The observed regularity that fiscal policy is much less effective in small, open economies depends on the crucial (implicit) assumption that interest rates will react to fiscal policy, causing capital flows and hence changes in the exchange rate, which in turn counteract part of the initial impact. If the central bank uses policies supporting fiscal policy, again this conclusion must be questioned. However, despite these complications, the IMF's conclusions remain the best set of panel-data-based stylized facts we have at the moment and will thus be used in the rest of the paper.

5. According to the IMF, given that the impact of monetary policy is usually estimated in the literature, it might even be possible that all of the difference between the impact of spending cuts and tax increases is due to different monetary policy reactions. See IMF (2010a, p. 102). 
In addition to these stylized facts, the narrative of the Great Recession and the euro crisis as presented above adds the following points on fiscal policy:

- An important channel of fiscal policy at least in severe recessions (but potentially also in shallow recessions) is about the investors' expectations and hence private investment;

- An internationally-coordinated fiscal policy has larger impacts than isolated national policies.

As becomes evident by looking at the above lists, in the current debate only the impact of fiscal policies on the demand side of the economy is covered. However, there is growing evidence that fiscal policy also has important effects on aggregate supply, as has been argued for the European case by Dullien and Schwarzer (2009). According to this argument, the failure of fiscal stabilization (and furthermore the amplification of the business cycle by severe fiscal tightening in a down-turn) leads to large fluctuations in aggregate demand, which have a negative impact on aggregate supply through channels of labor market hysteresis or through diminished research and development by the private sector (Aghion and Howitt 2006). While the impact of fiscal stabilization and fiscal tightening on aggregate supply is a very important one, it is not covered further in this article as none of the dominant models allows for such an effect and this type of mechanics has been largely outside the international policy debate over recent years.

\section{FISCAL POLICY IN KEYNESIAN MODELS}

Given the above list of stylized facts, an interesting question is how far Keynesian models mirror it. While models cannot be perfect reflections of reality, their results should at least be in line with the most important characteristics of real-world experiences.

\subsection{Old Keynesian models}

The most widely used ‘old Keynesian' model is still Hicks's (1937) IS-LM model. For generations, it has remained part of undergraduate textbooks. Even economists originally skeptical of traditional Keynesian economics, such as Gregory Mankiw, have re-introduced a treatment of the IS-LM model in the post-crisis editions of their textbooks. ${ }^{6}$ Moreover, IS-LM is still used by financial market analysts for getting a first approximation of the impact of policy measures on output as well as for policy analysis in institutions like the US Council of Economic Advisors (Mankiw 2006).

As is well known, in the IS-LM model a change in the fiscal policy stance is modeled as a shift of the IS-curve (to the right in the case of expansionary fiscal policy, to the left in the case of contractionary fiscal policy). Output contracts here when government spending is cut or taxes are increased, and expands when government spending is increased or taxes are cut. Moreover, the impact depends on the level of interest rates. If interest rates are already so low that even an increase in the money supply will not induce investors to lend out their money (the liquidity trap), fiscal policy is more potent. Changes in government expenditure have a larger impact than those due to taxes.

6. The second edition of Mankiw and Taylor (2008), published in 2011, contains a new chapter 33 title, 'Keynes and the IS-LM analysis,' which was not part of the original book. 
Measured against the stylized facts, the IS-LM model thus describes reasonably well the direction of the impact of fiscal policy. It also captures the fact that fiscal policy is more effective when interest rates are close to zero. ${ }^{7}$ However, it does not say anything about the interaction with the exchange rate regimes and policies in other countries. It also neglects questions of solvency and it does not predict any positive impact of fiscal expansions on private investment. Its conclusion on the effectiveness of changes in government outlays and revenue is not quite what the stylized facts would say. However, to be fair, it is also not clear from the stylized facts how much of this specific observation is caused by endogenous reaction of monetary policy.

The interaction with the external sector is modeled in the Mundell-Fleming extension of the IS-LM model. Here, net exports as a function of domestic demand, foreign demand and the real exchange rate are added to the aggregate demand function. In addition, a balance of payment curve with interest-sensitive capital flows is introduced. In this framework, the Mundell-Fleming model mimics many of the IS-LM's results: spending cuts and tax increases lower output, and the magnitude depends on the interest elasticity of the money demand function. However, the extension by an external sector provides additional insights. Fiscal policy becomes less effective for a small, open economy. Moreover, fiscal policy is more effective in the case of fixed exchange rates. If exchange rates are flexible, by contrast, fiscal policy loses its effectiveness. Spending cuts then lead to a depreciation of the domestic currency and the improvement of net export demand compensates for the shortfall in domestic demand. If one constructs a Mundell-Fleming model for two countries, coordinated fiscal policy can be shown to be more effective than fiscal stimulus enacted in one country only.

Comparing these predictions with the stylized facts, we see that the MundellFleming model could very well portray the effects of fiscal policy expected for an open economy. The direction of the impact of changes in government spending is directly and rightly captured. Moreover, the model correctly links the stylized facts concerning the size and the interaction with the exchange rate regime. The failure of the IS-LM to capture certain domestic effects of fiscal policy (solvency issues and investors' confidence), however, remain valid for the Mundell-Fleming extension as well.

\subsection{First generation New Keynesian models}

With the Rational Expectations Revolution triggered by Lucas (1972), the academic profession of economics shifted its work from using models with functional relationships between macroeconomic aggregates towards models with explicit microeconomic foundations. One important development was the emergence of Real Business-Cycle (RBC) models, based on the work by Kydland and Prescott (1982). In these models, the economy is depicted as the aggregation of a number of identical, representative agents with infinite horizons. These agents maximized lifetime utility by varying labor supply, consumption and saving over their lifetime. Business cycle fluctuations were caused by random shocks to productivity and tastes and the individuals' reaction to it. The main mechanism by which these shocks to productivity led to

7. This conclusion goes in a similar direction to Galí's (1992) conclusion that the IS-LM model augmented by a Philips curve describes the US postwar data reasonably well. Note, however, that some of Galí's conclusions are problematic. For example, the large share of fluctuations Galí attributes to the supply side directly follow from his questionable assumption that any shock which has a lasting influence on GDP needs to be a supply-side shock. 
fluctuations in GDP was that changes in productivity led to changes in the real wage and that individuals then adjusted their labor supply accordingly. As these models assume that the labor market always and instantaneously cleared, these changes in the labor supply then led directly to changes in aggregate output. In short, business cycle fluctuations in these models were explained by the individuals' inter-temporal substitution between leisure and work depending on current and future expected real wages.

These models were clearly anti-Keynesian. There is no role for monetary or fiscal policy, and economic fluctuations are explained by supply-side shocks. In addition, while employment is changing over time, there are no welfare considerations to stabilize it. As the business cycle is the optimal reaction of individuals to external shocks, any attempt to stabilize it would lower welfare. All changes in employment in these models are voluntary and there is no room for involuntary unemployment.

As these models were unsatisfactory to many economists of Keynesian provenance and seemed at odds with the experience of disinflation policies' impact on output and employment, the New Keynesian research agenda of the 1990s consisted of attempts to include market frictions into models with rational expectations. One strand of research (quickly gaining influence in academic departments, international organizations and central banks) extended RBC models with various frictions in product and labor markets. The result was so-called Dynamic Stochastic General Equilibrium (DSGE) models, which were often referred to as 'optimizing IS-LM models' or 'New Neoclassical Synthesis,' underlying their Keynesian elements.

While these models kept the basic notion that macroeconomic fluctuations can be explained by the aggregation of the microeconomic reactions of representative agents, standard elements such as monopolistic competition (as pioneered by Blanchard and Kiyotaki (1987)) and staggered price setting (following Calvo (1983)) were added. These models were New Keynesian in the sense that they first exhibit some nonneutrality of monetary policy and second that they assume some market imperfections which may be crucial for understanding economic fluctuations, thus fulfilling Mankiw and Romer's (1991) criteria for New Keynesian theories. They quickly became standard theories for monetary policy analysis and remained so at least until the US subprime crisis (when they were criticized for not having been able to spot the growing problems), even though one needed to assume parameters for the micro-foundations (that is, for the elasticity of substitution between leisure and consumption) which were clearly at odds with what economists had measured in other studies. ${ }^{8}$

However, these models have seldom been applied to fiscal policy analysis. In fact, fiscal policy in these models had very peculiar and counter-intuitive effects (Linnemann 2006). Debt-financed increases in government spending leads to an increase in output and employment, but not through the income multiplier known in traditional Keynesian models. Instead, these models feature a drop in private consumption as a reaction to an increase in government spending. The mechanism behind this is similar to early attempts to introduce fiscal policy into the RBC models (Baxter and King 1993). As individuals have infinite horizons and rational expectations and the government is forced to respect its inter-temporal budget constraint, any debt-financed increase of government spending would lead to higher taxes in the future. This in turn is seen by the individuals as a drop in their discounted lifetime incomes. In order to compensate for this, individuals would decide to cut back both their private consumption and their enjoyment of leisure time and hence supply more labor. This

8. For a good discussion, see Tovar (2008). 
would lead to more employment and more output, but less private consumer expenditure.

Hence, while the impact of changes in government spending on output would come close to the stylized facts described above, both the empirical (positive) reaction of private consumption to increases in government spending and the possibility that fiscal policy stabilizes investors' expectations are not replicated by this class of models.

Mankiw (2006), despite being in favor of this class of models, concludes critically that the lack of use of the DSGE models for practical policy analysis might be due to the fact that, while these models may provide a coherent framework derived from first principles, they are not well suited to being applied to real-world problems: 'The fact that modern macroeconomic research is not widely used in practical policymaking is prima facie evidence that it is of little use for this purpose' (p. 43).

A related problem from a traditional Keynesian view is that the DSGE models are similar to the RBC models when it comes to the treatment of unemployment. All fluctuations in employment stem from the individuals' decisions to vary their labor supply. In addition, individuals are always able to fulfill their labor supply plans. There is thus no involuntary unemployment in these (so-called Keynesian) models.

\subsection{Post-crisis New Keynesian models}

Even before the onset of the crisis of 2008-2009, economists had tried hard to improve the coverage of fiscal policy in DSGE models. One of the goals was first to reconcile the empirical observation of the absence of Ricardian equivalence with the models, the second was to get more plausible effects from changes in fiscal policy on private consumption. Two main changes were introduced into the models - rule-of-thumb consumers and overlapping generations.

In models of rule-of-thumb consumers, it is assumed that a certain share of the population does not have access to financial markets. These individuals still maximize their lifetime utility through inter-temporal variation of hours worked; yet they always consume all of their current income as they can neither borrow nor save in financial markets. As Galí et al. (2004) show, if a significant share of individuals is of this type, the models' results get closer to the traditional Keynesian conclusion of both output and private consumption moving in sync with debt-financed government spending. In models of overlapping generations, in each period, some individuals die. As individuals are not sure whether a debt-financed increase in government spending really has to be borne by them (rather than by future generations), debt-financed spending now increases current demand more than proportionately to any reduction in private consumption to provide for future tax liabilities. Hence this mechanism provided a second channel through which traditional Keynesian results were re-introduced into DSGE models.

After the onset of the crisis, DSGE models were criticized for not modeling a financial sector and hence missing all the non-linear realities of boom-and-bust cycles. While economists had been working on the role of financial intermediaries and the impact of shocks due to disruptions in balance sheets of firms and those of the banks (see Bernanke et al. 1998), these attempts have remained at the fringes of DSGE research. The DSGE models badly underestimated the speed and momentum of the 2008-2009 recession (Wieland 2012) and it became clear that a more detailed modeling of financial intermediation would be necessary.

One of the most prominent attempts to introduce all of these elements into a DSGE framework is the IMF's Global Integrated Monetary and Financial Model (GIMF). It is 
a fully-fledged DSGE model with standard elements such as monopolistic competition and staggered price setting. It covers several regions that engage in balance-ofpayments and current account transactions. In each region, there are differentiated producers of raw materials, capital goods, and consumer goods, as well as import agents, distributors, retailers, and labor unions.

More central to the treatment of fiscal policy is the modeling of the household sector and the GIMF allows here both for overlapping generations and a certain share of rule-of-thumb consumers. It includes a financial sector in which banks give loans to entrepreneurs who in turn buy capital goods from capital goods producers and rent them out to manufacturers. As in the case of bankruptcies, banks can only recuperate part of their loans (and part of the market value of the collateralized capital goods), so there is an upward-sloping relationship between the external financing premium and the debt-to-equity ratio (or leverage) of entrepreneurs in the GIMF model. Moreover, the lower this external financing premium, the more investment in physical capital will be undertaken in the economy.

All in all, the GIMF is an extremely complex model which allows the simulation of a change to a number of detailed variables, including transfers to households and government purchases. However, the complexity comes at a price, the (brief) description of the underlying theoretical structure taking roughly 70 pages with 350 equations (Kumhof et al. 2010).

However, the alterations of the household sector and the introduction of a financial accelerator allow for rich reactions to fiscal policy by the economy as a whole. For example, if the share of consumers of the rule-of-thumb type is large enough, in this model debt-financed increases in government spending lead to an increase in output, employment, and private consumption. The models allow distinction between general transfers (to all individuals) and targeted transfers (to those who have no access to financial markets and who hence spend the additional income in the current period), with the result that targeted transfers have a much more pronounced impact.

Moreover, the financial accelerator allows for a plausible crowding-in of private investment through increased government spending. Effectively, it brings down the external financing premium through two channels. First, government spending increases aggregate demand, thus increasing economy-wide rates of capacity utilization of physical capital. This in turn increases the market value of existing (physical) capital goods and thus strengthens the equity base of the corporate sector. Second, increased aggregate demand pushes inflation up and lowers the real value of the corporate sector's stock of debt. Both mechanisms bring down the debt-to-equity ratio and hence the external financing premium, boosting private investment (Freedman et al. 2009).

A differentiated impact of fiscal policy for different underlying monetary policy conditions can also be nicely demonstrated. As Freedman et al. (2009) as well as the IMF (2010a) have shown, it can be assumed that monetary policy does not react to any changes in the inflation outlook for a given period of time (that is, two years). The logic behind such an assumption could be monetary policy being constrained by the zero bound. If interest rates are already close to zero, but economic conditions would warrant even more stimulus, a central bank would leave the policy rate unchanged even if inflation picks up. In such a case, fiscal policy has a larger impact as it additionally brings down the real interest rate as it creates inflationary pressure. This again is in line with the empirical finding that fiscal policy is more effective in situations where monetary policy cannot react.

Moreover, as the GIMF is a multi-country model, it is possible to simulate coordinated and uncoordinated fiscal policy actions. It can be shown that fiscal policy in one 
region of the world has the expected impact in other regions. Overall, a coordinated fiscal stimulus in all regions has a larger impact than an isolated stimulus packages (Freedman et al. 2009). In parallel, a coordinated fiscal tightening would have amplified effects, as any single region would then not only be hit by the negative effects of its own spending cuts, but also by those in other countries.

\section{CONCLUSIONS}

Table 1 summarizes which of the stylized facts on the impact of fiscal policy can actually be traced in the different models. The first striking point is how well traditional Keynesian models perform. Despite their age, they get a remarkable share of the stylized facts correct. Also extremely interesting is to see that modern New Keynesian models also get the basics right by now, and even allow for the detailed analysis of fiscal policy instruments. What really looks disappointing is the performance of traditional standard DSGE models, dubbed here as 'first generation New Keynesian models,' which were used prior to the Great Recession. They even got the basic directions of the impact of fiscal policy on private consumption and investment wrong.

However, before one now concludes that the GIMF and its class of models are vastly superior to the other models, one should think twice. First, the quality of an economic model is not merely measured by how close its conclusions are to reality. Clearly, a more complex model can be expected to perform much better than a simple model. However, in economics it is all about costs and benefits. Increased complexity comes at a cost. One needs a vast amount of experience with DSGE models and advanced knowledge of mathematics to really understand which economic mechanisms actually are at play in the model. For teaching economics at a graduate (let

Table 1 Main features of the treatment of fiscal policy in different Keynesian models

\begin{tabular}{|c|c|c|c|c|}
\hline & IS-LM & $\begin{array}{l}\text { Mundell- } \\
\text { Fleming }\end{array}$ & $\begin{array}{c}\text { First } \\
\text { generation } \\
\text { New } \\
\text { Keynesian } \\
\text { Models }\end{array}$ & $\begin{array}{c}\text { Second } \\
\text { generation } \\
\text { New } \\
\text { Keynesian } \\
\text { Models } \\
\text { (GIMF) }\end{array}$ \\
\hline Spending cuts are contractionary & Yes & Yes & Yes & Yes \\
\hline $\begin{array}{l}\text { Spending cuts lead to contraction of } \\
\text { private domestic demand }\end{array}$ & Yes & Yes & No & Yes \\
\hline $\begin{array}{l}\text { Impact of fiscal policy is larger if } \\
\text { interest rates are close to zero }\end{array}$ & Yes & Yes & Yes & Yes \\
\hline $\begin{array}{l}\text { Fiscal tightening through tax increases } \\
\text { is more contractionary than through } \\
\text { spending cuts }\end{array}$ & No & No & Yes & Yes \\
\hline $\begin{array}{l}\text { Impact of fiscal policy is larger for } \\
\text { closed economies }\end{array}$ & Not modeled & Yes & Not modeled & Yes \\
\hline $\begin{array}{l}\text { Impact of fiscal policy is larger with } \\
\text { fixed exchange rates }\end{array}$ & Not modeled & Yes & Not modeled & Yes \\
\hline $\begin{array}{l}\text { Expansionary fiscal policy has positive } \\
\text { influence on private investment }\end{array}$ & No & No & No & Possibly \\
\hline Involuntary unemployment & Yes & Yes & No & No \\
\hline
\end{tabular}


alone undergraduate) level, which is an exercise in thinking in causes and effects, the DSGE model (and even more so the GIMF model) is clearly not suitable. One can thus question whether the vast amount of manpower, software and computing power going into an analysis with such a model is worth the additional insight created from moving from old Keynesian models to the most recent New Keynesian models.

Especially, the underlying economic mechanism in the GIMF model is still the same as in the earlier DSGE models. Observed fluctuations in employment and output still stem from the individuals' intertemporal substitution between labor supply and leisure time. In other words, unemployment in this model is still always voluntary. The underlying parameters one needs to plug into some of the behavioral equations such as the utility function are still way off most of the estimates from microeconomic research.

In how far this remains a problem, of course, is open to debate. Faust (2012) argues that in medical experiments, rats are regularly used instead of humans. According to him, rats clearly are different from humans and certain mechanisms are clearly different between humans and rodents. Yet, there are important conclusions to be drawn from the animal experiments. Hence, one should trust at least as much in DSGE models as one does in animal experiments.

Dullien (2011) by contrast argues that one should be much more careful using a model with dubious underlying assumptions and micro-mechanics. Using a model that relies on a microstructure that strikes one as implausible or outright wrong must be highly problematic. This can be seen when looking at the so-called Turing test. During the 1960s and 1970s, this test (named after Alan Turing) was regularly used to evaluate artificial intelligence. According to this test, a piece of computer software had artificial intelligence if a person was not able to distinguish whether she was communicating with a computer or a real human being. In consequence, a number of increasingly sophisticated programs were written, mimicking human reactions to certain inputs, the most famous of which was 'Eliza.' 'Eliza' reacted to keywords only, but had actually managed to fool some people. Recent versions of this software actually do a pretty good job at pretending to be human. Yet mimicking certain outcomes and reactions is very different from producing these outcomes oneself. While a piece of software passing the Turing test might make great entertainment, you would never want to use the software to simulate how your mother-in-law would react if you told her that the family would not be coming to her 75th birthday celebration.

While drawing parallels to other disciplines always carries the risk of being misleading, the Turing analogy seems to be much better than Faust's rodent analogy. A rat and a human being have clearly similar underlying structures (such as biochemical and physical laws). The DSGE model's building blocks, both in terms of individual decision-making as well the functioning of the labor market, are arguably very different from empirical reality (or at least very different from what many Keynesian economists believe it to be). It might thus be safe to use the model for instances in which its reliability has been proven beyond doubt, yet one should beware of using it for investigating new questions.

In conclusion, it is therefore difficult to assess how much progress really has been made in the coverage of fiscal policy in Keynesian models over the past 75 years. Cynics might argue that there has been a U-shaped development of knowledge. There has been a loss of insight with the movement towards the first generation of DSGE models and a new gain of insight with the most recent models. Whether we are now above or below the level of insight from the middle of the 20th century depends on how much one values precision and how much one values tractability. 


\section{REFERENCES}

Aghion, P. and P. Howitt (2006), 'Joseph Schumpeter Lecture Appropriate Growth Policy: A Unifying Framework,' Journal of the European Economic Association, 4, 269-314.

Alesina, A. and S. Ardagna (1998), 'Tales of Fiscal Adjustment,' Economic Policy, 13 (27), 498-545. Alesina, A. and S. Ardagna (2009), 'Large Changes in Fiscal Policy: Taxes Versus Spending,' NBER Working Paper 15438.

Auerbach, J. A. and Y. Gorodnichenko (2011), 'Fiscal Multipliers in Recession and Expansion,' NBER Working Paper 17447.

Barro, R. (2009), 'Government Spending is No Free Lunch,' Wall Street Journal, January 22.

Baxter, M. and R. G. King (1993), 'Fiscal Policy in General Equilibrium,' American Economic Review, 83 (3), 315-334.

Bernanke, B. S., M. Gertler, and S. Gilchrist (1998), 'The Financial Accelerator in a Quantitative Business Cycle Framework,' NBER Working Paper 6455.

Blanchard, O. J. and N. Kiyotaki (1987), 'Monopolistic Competition and the Effects of Aggregate Demand,' American Economic Review, 77 (4), 647-666.

Blinder, A. (2006), 'The Case Against the Case Against Discretionary Fiscal Policy,' in R. W. Kopcke, G. M. B. Tootell, and R. K. Triest (eds), The Macroeconomics of Fiscal Policy, Cambridge, MA: MIT Press, pp. 25-61.

Calvo, G. (1983), 'Staggered Prices in a Utility-Maximizing Framework,' Journal of Monetary Economics, 12 (3), 383-398.

Coy, P. (2010), 'Keynes vs Alesina. Alesina Who?' Business Week, June 30.

DeLong, J. B. (2012), 'Spending Cuts to Improve Confidence? No, the Arithmetic goes the Wrong Way,' VoxEU.org, April 6.

Devries, P., J. Guajardo, D. Leigh, and A. Pescatori (2011), 'A New Action-based Dataset of Fiscal Consolidation,' IMF Working Paper No. 11/128.

Dullien, S. (2011), 'The New Consensus from a Traditional Keynesian and Post-Keynesian Perspective,' Économie Appliquée, 64 (1), 173-200.

Dullien, S. and D. Schwarzer (2009), 'Bringing Macroeconomics into the EU Budget Debate: Why and How?' Journal for Common Market Studies, 47 (1), 153-174.

EU Commission (2011), European Economic Forecast Autumn, Brussels.

EU Commission (2012), European Economic Forecast Spring, Brussels.

Faust, J. (2012), 'DSGE Models: I Smell a Rat (and It Smells Good),' International Journal of Central Banking, 8 (1), 53-64.

Feldstein, M. (2002), 'Tax Cuts, Rate Cuts Put the Economy Back on Track,' Wall Street Journal, March 13.

Freedman, C., M. Kumhof, D. Laxton, D. Muir, and S. Mursula (2009), 'Fiscal Stimulus to the Rescue? Short-Run Benefits and Potential Long-Run Costs of Fiscal Deficits', IMF Working Paper WP/09/255, Washington, DC.

Galí, J. (1992), 'How Well Does the IS-LM Model Fit Postwar U.S. Data?' Quarterly Journal of Economics, 107 (2), 29-46.

Galí, J., J. D. Lopez-Salido, and J. Valles (2004), 'Rule-of-Thumb Consumers and the Design of Interest Rate Rules,' NBER Working Paper 10392.

Giavazzi F. and M. Pagano (1990), 'Can Severe Fiscal Contractions be Expansionary? Tales of Two Small European Countries,' NBER Macroeconomics Annual, 5, 75-111.

Gros, D. (2011), 'Can Austerity be Self-defeating?' VoxEU.org, November 29.

Hicks, J. R. (1937), 'Mr. Keynes and the "Classics": a Suggested Interpretation,' Econometrica, 5 (2) $19-54$.

IMF (2010a), 'Will it Hurt? Macroeconomic Effects of Fiscal Consolidation,' World Economic Outlook, October, 93-124.

IMF (2010b), 'Greece: First Review Under the Stand-by Arrangement,' Washington, DC.

IMF (2011), 'Greece: Fifth Review Under the Stand-by Arrangement,' Washington, DC.

Keynes, J. M. (1936), The General Theory of Employment, Interest, and Money, London: Macmillan. 
Kumhof, M., D. Laxton, D. Muir, and S. Mursula (2010), 'The Global Integrated Monetary and Fiscal Model (GIMF) - Theoretical Structure,' IMF Working Paper WP/10/34.

Kydland, F. and E. C. Prescott (1982), 'Time to Build and Aggregate Fluctuations', Econometrica, 50 (6), 1345-1370.

Linnemann, L. (2006), 'The Effect of Government Spending on Private Consumption: A Puzzle?' Journal of Money, Credit, and Banking, 38 (7), 1715-1735.

Lucas, R. E. (1972), 'Expectations and the Neutrality of Money', Journal of Economic Theory, 4, 103-124.

Mankiw, N. G. (2006), 'The Macroeconomist as Scientist and Engineer,' Journal of Economic Perspectives, 20 (4), 29-46.

Mankiw, N. G. and D. Romer (eds) (1991), New Keynesian Economics, Cambridge, MA: MIT Press.

Mankiw, N. G. and M. P. Taylor (2008), Economics, Andover: South-Western.

OECD (2009), 'The Effectiveness and Scope of Fiscal Stimulus', OECD Interim Economic Outlook (March), Chapter 3, Paris.

Perotti, R. (2011), 'The “Austerity Myth”: Gain Without Pain,' NBER Working Paper 17571.

Reinhart, C. M. and K. S. Rogoff (2009), This Time is Different, Princeton and Oxford: Princeton University Press.

Romer, D. (1996), Advanced Macroeconomics, New York: McGraw-Hill.

Spilimbergo, A., S. Symansky, and M. Schindler (2009), 'Fiscal Multipliers,' IMF Staff Position Note SPN/09/11, Washington, DC.

Tovar, C. E. (2008), 'DSGE Models and Central Banks', BIS Working Papers 258, Basel.

UNCTAD (2011), 'Trade and Development Report 2011,' Geneva.

Wieland, V. (2012), 'Model Comparison and Robustness: A Proposal for Policy Analysis After the Financial Crisis', in R. M. Solow and J.-P. Touffut (eds), What's Right with Macroeconomics?, Cheltenham, UK, and Northampton, USA: Edward Elgar. 